\title{
Political skill and organizational identification: Preventing role ambiguity from hindering organizational citizenship behaviour
}

\author{
Dirk De Clercq ${ }^{1 \star}$ and Imanol Belausteguigoitia ${ }^{2}$ \\ ${ }^{1}$ Goodman School of Business, Brock University, St. Catharines, Ontario L2S 3A1, Canada and ${ }^{2}$ Instituto Tecnológico \\ Autónomo de México (ITAM), Santa Teresa Campus, Mexico City, Mexico \\ ${ }^{*}$ Corresponding author. Email: ddeclercq@brocku.ca
}

(Received 9 June 2018; accepted 3 April 2019; first published online 9 May 2019)

\begin{abstract}
This research investigates how employees' perceptions of role ambiguity might inhibit their propensity to engage in organizational citizenship behaviour (OCB), with a particular focus on the potential buffering roles of two personal resources in this process: political skill and organizational identification. Survey data collected from a manufacturing organization indicate that role ambiguity diminishes OCB, but this effect is attenuated when employees are equipped with political skill and have a strong sense of belonging to their organization. The buffering role of organizational identification also is particularly strong when employees have adequate political skills, suggesting the reinforcing, buffering roles of these two personal resources. Organizations that want to foster voluntary work behaviours, even if they cannot provide clear role descriptions for their employees, should nurture adequate personal resources within their employee ranks.
\end{abstract}

Keywords: organizational citizenship behaviour; role ambiguity; political skill; organizational identification

\section{Introduction}

Organizational citizenship behaviour (OCB) refers to discretionary activities that are not formally rewarded and extend beyond formal job duties but that can be instrumental to team and organizational effectiveness (Bachrach, Powell, Collins, \& Richey, 2006; Borman \& Motowidlo, 1993; Lin \& Peng, 2010; Podsakoff, Ahearne, \& MacKenzie, 1997). They also can benefit employees themselves, by providing sources of personal satisfaction and meaningfulness (Borman \& Motowidlo, 1993) that might fuel their career development and success (Lievens, De Corte, \& Schollaert, 2008; Russo, Guo, \& Baruch, 2014). Prior research accordingly addresses why some employees appear more likely than others to engage in $\mathrm{OCB}$, usually by focusing on positive factors that can spur OCB - whether personal factors, such as job satisfaction, organizational commitment (Williams \& Anderson, 1991), work engagement (Rurkkhum \& Bartlett, 2012), proactive personalities (Li, Liang, \& Crant, 2010), or personal values (Arthaud-Day, Rode, \& Turnley, 2012), or contextual factors, such as person-organization fit (Wei, 2012), constructive feedback (Sommer \& Kulkarni, 2012), organizational justice (Schilpzand, Martins, Kirkman, Lowe, \& Chen, 2013), decision autonomy (Noblet, McWilliams, Teo, \& Rodwell, 2006), ethical decision making (Shin, 2012), or servant leadership (Ozyilmaz \& Cicek, 2015). ${ }^{1}$

\footnotetext{
${ }^{1}$ This list is not exhaustive; for recent reviews of OCB research, see Ocampo, Acedillo, Bacunador, Balo, Lagdameo, \& Tupa (2018) or Rose (2016).

๑ C Cambridge University Press and Australian and New Zealand Academy of Management 2019.
} 
Alternatively, adverse working conditions might steer employees away from OCB, such as dysfunctional organizational politics (De Clercq \& Belausteguigoitia, 2017a), excessive workloads (Noblet et al., 2006), interpersonal conflicts (Pooja, De Clercq, \& Belausteguigoitia, 2016), perceived contract breaches (Zhao, Wayne, Glibkowski, \& Bravo, 2007), and role stress (Eatough, Chang, Miloslavic, \& Johnson, 2011). This consideration of negative factors is important because unfavourable, resource-draining situations can deprive employees of the energy they need to undertake discretionary work activities such as OCB (Hobfoll \& Shirom, 2000; Priesemuth \& Taylor, 2016). What these factors have in common is that they create significant uncertainty about employees' ability to perform their regular job tasks, which might make them reluctant to take on additional activities. Because OCB requires residual work energy that cannot be devoted to formally prescribed job duties (Organ, 1988; Podsakoff, Whiting, Podsakoff, \& Blume, 2009), understanding whether and when uncertainty-inducing work conditions diminish OCB is critical for organizational decision makers (Tremblay \& Gibson, 2016; Zhang, Walumbwa, Aryee, \& Chen, 2013).

A specific source of uncertainty for employees is the experience of role ambiguity or the extent to which they are unclear about what their job responsibilities entail (Fried \& Tiegs, 1995; Kahn, Wolfe, Quinn, Snoek, \& Rosenthal, 1964). It represents a significant source of stress and frustration for employees because it obscures what they should do to comply with employer expectations (Schmidt, Roesler, Kusserow, \& Rau, 2014; Trépanier, Fernet, \& Austin, 2013). Notably, ruminations about unspecified job obligations likely diminish the personal energy that employees have available to devote to discretionary work behaviours (Hobfoll, 2001; Quinn, Spreitzer, \& Lam, 2012). The key objective of this study accordingly is to investigate how role ambiguity might diminish the likelihood that employees engage in $\mathrm{OCB}$, with a particular focus on the potential mitigating effects of two personal resources: employees' political skill, or their social competencies to understand and influence their organizational environment (Perrewé et al., 2005), ${ }^{2}$ and their organizational identification, or the extent to which they feel a strong sense of belonging to their organization and experience its successes and failures as their own (Brammer, He, \& Mellahi, 2015).

Our theoretical arguments are anchored in the conservation of resources (COR) theory (Hobfoll, 1989, 2001). According to this theory, negative job experiences tend to divert employees from discretionary work behaviours because they suffer depletion of their energy resources as a result of their experiences (Hobfoll \& Shirom, 2000). This theory also predicts an essential role of employees' personal resources, in that they may function as buffers of this process (Abbas, Raja, Darr, \& Bouckenooghe, 2014; Hobfoll, 2001; Witt \& Carlson, 2006). The predicted moderating roles of the two focal personal resources in our conceptual model (political skill and organizational identification) are consistent with this buffering logic. That is, both resources provide employees with the energy needed to maintain some level of OCB, despite the presence of resource-draining role ambiguity (Chen, Lin, \& Lien, 2011; Schmidt et al., 2014).

We seek to make several contributions to this study. First, we examine role ambiguity as an inhibitor of OCB, with a central focus on when this resource-depleting work condition might be less likely to exert a negative effect. We accordingly respond to calls for more applications of contingency approaches to study role stress outcomes (Chen, Takeuchi, \& Shum, 2013; De Clercq \& Belausteguigoitia, 2017b; Ralston et al., 2010) and for explications of how resourcedraining work conditions may prevent employees from performing voluntary work behaviours (Naseer, Raja, Syed, Donia, \& Darr, 2016; Noblet et al., 2006; Paillé, 2011). We postulate that employees' negative responses to unclear role descriptions, in the form of reduced OCB, may be mitigated by two distinct personal resources: their capabilities to cope with workplace adversity (i.e., political skill; Ferris, Treadway, Perrewé, Brouer, Douglas, and Lux, 2007) and their positive

\footnotetext{
${ }^{2}$ The notion of political skill is distinct from political savvy, which captures employees' 'adeptness at the nuances of politics in organizations' (Ferris et al., 2005: 130). That is, political savvy is narrower than political skill and relates most closely to the latter's social astuteness dimension (Ferris et al., 2005).
} 
emotional perspective that makes them more forgiving of organizational hardships (i.e., organizational identification; Liu, Loi, and Lam, 2011). Notably, these two personal resources complement each other, in that they speak to employees' ability and motivation, respectively, to undertake discretionary work behaviours in the presence of role ambiguity. Investigating these two contingency factors thus creates a consistent, comprehensive portrait of how employees' personal resources may mitigate the risk that they avoid OCB in the presence of unclear job descriptions.

Second, to achieve an even better understanding of the harmful outcomes of role ambiguity, we consider the interplay of the personal resources of political skill and organizational identification. That is, we explicate their interdependent, reinforcing effects in terms of buffering the negative effect of role ambiguity on $\mathrm{OCB}$, an issue that has received relatively little attention in previous empirical applications of COR theory (Hobfoll, 2011). In particular, we show that organizational identification can buffer the harmful effect of role ambiguity on OCB, but its relative usefulness increases to the extent that employees can draw from their political competencies. This finding, in turn, implies the presence of positive resource spirals that can mitigate employees' negative responses to role ambiguity (Hobfoll, 2001).

Third, our study takes place in Mexico, an understudied context that is relevant to the research objectives. This country is characterized by high levels of uncertainty avoidance, and people in this culture likely feel distressed by ambivalent, unstructured situations, so they might suffer when they confront a lack of relevant information about how to perform their job tasks (Hofstede, Hofstede, \& Minkov, 2010). The central issue of this study - the usefulness and influence of relevant personal resources for buffering the relationship between role ambiguity and OCB - thus should be particularly pertinent in our study context, as well as for other countries with cultural profiles similar to Mexico's.

The conceptual framework is in Figure 1. We detail its constitutive hypotheses next.

\section{Research Hypotheses}

\section{Role ambiguity and $O C B$}

When employees receive insufficient information about their job responsibilities, they tend to grow concerned about their organizational functioning and long-term success (Singh, Suar, \& Leiter, 2012; Zhou, Martinez, Ferreira, \& Rodrigues, 2016). We explicitly acknowledge that such role ambiguity may diminish both the ability and the motivation of employees to undertake OCB. First, employees who face uncertainty-inducing work conditions tend to react with cognitive coping mechanisms that consume substantial energy (Hobfoll \& Shirom, 2000; Lazarus \& Folkman, 1984), such that they have less energy available to dedicate to discretionary activities that are not formally required by their job descriptions (Quinn, Spreitzer, \& Lam, 2012). Voluntary work behaviours require substantial energy (Podsakoff et al., 2009), and employees who are preoccupied with information shortages about their job responsibilities may not possess that level of energy (Schmidt et al., 2014). Notably, employees tend to feel exhausted when trying to figure out what their employer expects from them (Singh, Suar, \& Leiter, 2012), so they may consider OCB a significant distraction that prevents them from fulfilling their job duties. In the presence of role ambiguity, undertaking OCB might be beyond employees' reach or capability.

In addition to thwarting their ability to undertake voluntary work behaviours, unclear role descriptions may diminish employees' motivations to perform them. That is, the resource drainage that comes with role ambiguity might translate into lower OCB because employees have a desire to avoid further resource losses, as might be manifested in an inability to perform their formal job duties (Trépanier, Fernet, \& Austin, 2013), so they conserve their work-related energy, including energy that they otherwise would devote to voluntary efforts to enhance organizational well-being (Curran \& Prottas, 2017; Hobfoll, 2001). Moreover, incomplete job information may signal disrespect from the organization (Kahn et al., 1964; O'Driscoll \& Beehr, 2000), to which 


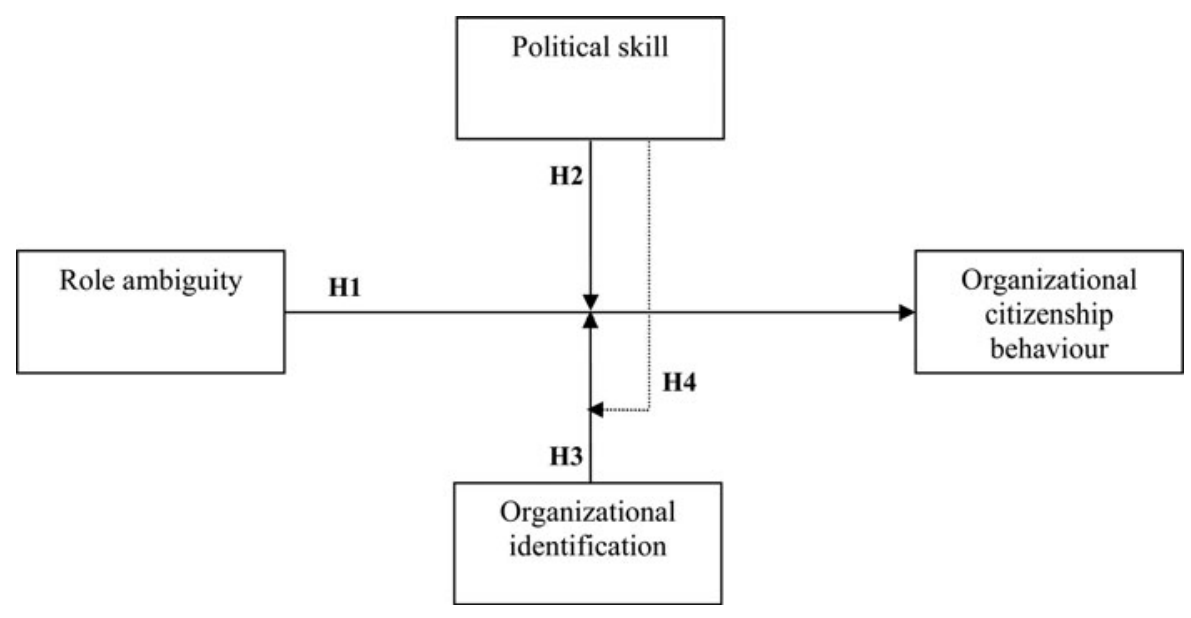

Figure 1. Conceptual model.

employees may respond with a reduced willingness to contribute to organizational effectiveness (Podsakoff et al., 2009). If employees sense that their employer cares little about their well-being because it fails to provide adequate guidance about their job duties, they might have little reason to devote themselves to its success (Zhang, Tsingan, \& Zhang, 2013). Instead, they might conserve their energy resources and only allocate personal energy to activities that are formally rewarded (Eatough et al., 2001; Hobfoll, 2001).

Hypothesis 1: There is a negative relationship between employees' experience of role ambiguity and their organizational citizenship behaviour.

\section{Moderating role of political skill}

According to COR theory, the resource-depleting effect of employees' exposure to unfavourable work conditions on their likelihood to undertake discretionary work behaviours is attenuated to the extent that they can compensate for the resource loss through their personal resources (Abbas et al., 2014; Hobfoll, 1989). We propose that their political skill is a useful resource in this regard because it mitigates the reduced ability of employees to engage in OCB in the presence of an adverse work condition such as role ambiguity (Hochwarter, Ferris, Gavin, Perrewé, Hall, \& Frink, 2007) Politically skilled employees can cope more effectively with information deficiencies in job descriptions, by exerting their personal influence over other organizational members and soliciting advice about how to deal with the stressful situation (Bing, Davison, Minor, Novicevic, \& Frink, 2011; Ferris, Davidson, \& Perrewé, 2005). Politically competent employees possess strong abilities to get other members to provide them with valuable insights, such as about ways to combine regular job duties with voluntary activities successfully, even in the presence of energy-draining role ambiguity (Kolodinsky, Treadway, \& Ferris, 2007). Ultimately these employees should feel less drained by the absence of clear job descriptions (Schmidt et al., 2014) and have greater means to undertake voluntary work behaviours.

The social astuteness of politically skilled employees (Munyon, Summers, Thompson, \& Ferris, 2015) also may grant them a greater understanding of how they could benefit from voluntary work efforts (e.g., personal reputation building, career advancement; Russo, Guo, and Baruch, 2014) when their job descriptions are vague and grant them leeway in terms of how to allocate their personal energy (Fuller, Marler, and Hester, 2006; Morrison, 1994). That is, the depletion in 
energy due to this adverse work situation might be compensated for by an enhanced ability to perceive how personal resource gains can arise from engaging in OCB (Hobfoll \& Shirom, 2000). In contrast, employees with less political skill cannot protect themselves as well against the energy drainage that results from role ambiguity, due to their minimal ability to understand or leverage this situation (Ferris, Davidson, \& Perrewé, 2005; Zhao \& Xia, 2017). For example, they might be less able to find effective ways to deal with role ambiguity through feedback obtained from colleagues (Kolodinsky, Treadway, \& Ferris, 2007), so instead they must ruminate more about what their job responsibilities might entail, eventually leaving them with less energy for discretionary work activities such as OCB (Quinn, Spreitzer, \& Lam, 2012).

Overall, employees' political competencies should function as a buffer against a reduced ability to engage in OCB in the presence of role ambiguity; the relationship between these two factors should be weaker among employees who are more politically skilled (Hobfoll, 2001). Conversely, absent adequate political skills, the energy depletion resulting from enhanced ruminations about information shortages (Trépanier, Fernet, \& Austin, 2013) likely escalates into a diminished inclination to carry out voluntary work behaviours because of the employees' reduced ability to perform these behaviours in the adverse work situation.

Hypothesis 2: The negative relationship between employees' experience of role ambiguity and their organizational citizenship behaviour is moderated by their political skill, such that the relationship is weaker at higher levels of political skill.

\section{Moderating role of organizational identification}

We also hypothesize a buffering role of organizational identification; the likelihood that role ambiguity escalates into lower OCB should be subdued to the extent that employees have a stronger sense of belonging to their organization. In contrast with political skill, this buffering role speaks to the lower motivation that employees might have to stay away from OCB in the presence of role ambiguity. Employees who strongly identify with their organization experience their work environment as safer and more accommodating of their needs (Mael \& Ashforth, 1992; Riketta, 2005), so they tend to accept how their employer manages its workforce, even if certain practices might seem frustrating or hinder their organizational functioning (Ashforth, Harrison, \& Gorley, 2008). This sense of organizational identification should help counter employees' desire to conserve resources by not contributing voluntarily to their organization's success in response to role ambiguity (Hobfoll, 2001) because they are more forgiving of their employer, even if it creates stressful, resource-draining work conditions by failing to provide sufficient information about their job responsibilities (Brickson, 2013; Liu, Loi, \& Lam, 2011).

Similarly, high levels of organizational identification tend to shift employees' attention, from expecting personal comfort while undertaking their daily job tasks - which might be compromised in the presence of unclear job descriptions (Schmidt et al., 2014) - to sensing the need to contribute to organizational well-being with discretionary work behaviours (Van Knippenberg, 2000; Wang, Tang, Naumann, \& Wang, 2019). That is, employees who strongly identify with their organization likely assign less weight to the hardships associated with information deficiencies about their job descriptions, so consistent with the COR logic, it becomes less likely that their frustration about role ambiguity undermines their motivation to undertake OCB (Hobfoll \& Shirom, 2000). In contrast, employees with a low sense of organizational identification likely feel offended by the hardships associated with persistent job-related information shortages, and they accordingly may be less motivated to maintain some level of OCB in the presence of role ambiguity.

In summary, employees who strongly identify with their organization perceive their work environment as more supportive (Riketta, 2005) and should be more accepting of the notion that their organization may need to maintain some unfavourable practices, such as those that 
create uncertainty about their organizational functioning (Liu, Loi, \& Lam, 2011). These employees are less likely to avoid OCB in the presence of role ambiguity. In contrast, employees who do not possess a sense of organizational identification may be motivated to conserve their resources and reduce any work behaviours for which they are not formally rewarded in the presence of role ambiguity (Hobfoll \& Shirom, 2000).

Hypothesis 3: The negative relationship between employees' experience of role ambiguity and their organizational citizenship behaviour is moderated by their organizational identification, such that the relationship is weaker at higher levels of organizational identification.

Finally, we hypothesize that the buffering effect of organizational identification on the negative relationship between role ambiguity and OCB is particularly strong for employees who also can rely on adequate political skills. That is, we predict a three-way interaction among role ambiguity, organizational identification, and political skill. This argument is based on the concept of positive resource spirals from COR theory (Hobfoll, 2001), according to which energy-enhancing personal resources reinforce one another in mitigating the negative consequences of resource-draining work conditions.

That is, in Hypothesis 3, we postulated that when employees possess positive emotions about their employer (i.e., organizational identification), they experience the adverse work situation of role ambiguity as more acceptable and remain motivated to engage in some OCB (Riketta, 2005; Van Knippenberg, 2000). If they also can count on adequate political skill, the positive feelings associated with their strong sense of organizational identification should be particularly useful for helping them reserve some discretionary energy for voluntary activities in the presence of role ambiguity because they have an increased ability to channel these positive feelings into solutions, by obtaining valuable insights from organizational peers (e.g., Ferris, Davidson, \& Perrewé, 2005; Kolodinsky, Treadway, \& Ferris, 2007). Thus, the COR logic of positive resource spirals, which emphasizes the reinforcing, beneficial roles of different personal resources (Hobfoll, 2001), suggests that when employees can rely on their political skill, the extent to which they strongly identify with their organization and seek to ensure its well-being should be particularly useful for mitigating the negative effect of experiences of resource-draining role ambiguity on their OCB.

Conversely, employees without adequate political skills may have more difficulty leveraging positive emotions about their organization to protect against the hardship of resource-draining role ambiguity because they have less easy access to valuable knowledge resources that their organizational colleagues might possess in terms of how to combine their regular job tasks with voluntary work activities (Ferris, Davidson, \& Perrewé, 2005; Sun \& van Emmerik, 2015). In this case, the buffering effect of the personal resource of organizational identification on the negative relationship between role ambiguity and OCB should have less incremental importance (Hobfoll, 2001). That is, the positive energy directed toward the organization still mitigates the negative relationship, but it might be less powerful in terms of countering the frustration that comes with role ambiguity because employees lack the competencies to devote their positive energy toward influencing and possibly changing the situation (Perrewé et al., 2005). With insufficient political competencies, employees' organizational identification should have a weaker buffering effect on the role of ambiguity-OCB relationship.

Hypothesis 4: The buffering effect of organizational identification on the negative relationship between employees' experience of role ambiguity and their organizational citizenship behaviour is moderated by their political skill, such that this buffering effect is stronger among employees who are more politically skilled. 


\section{Method}

\section{Sample and data collection}

We tested the research hypotheses with data collected from employees who worked in a Mexican-based organization that manufactures motor vehicle parts and accessories. Investigating a single organization helped us avoid the risk of unobserved differences in the organizational culture or external market pressures, which could affect the time available for employees to undertake voluntary work behaviours (Hodson, 2002; Organ, 1988; Podsakoff et al., 2009). In addition, the company functions in a transitional economy, marked by high levels of collectivism and uncertainty avoidance (Hofstede, Hofstede, \& Minkov, 2010), so it makes for a compelling research setting because positive work behaviours such as OCB likely are widely encouraged, yet employees also could be sensitive to the presence of uncertainty-inducing work conditions.

After receiving support from the organization's top management, we asked 250 randomly selected individual employees to participate in a survey. Following a well-established procedure (Brislin, Lonner, \& Thorndike, 1973), the original English survey was translated into Spanish, then back-translated into English. After checking for discrepancies between the two English versions, the Spanish version was finalized. We also pretested a preliminary version of the survey with five employees who did not participate in the actual data collection and incorporated their feedback, to improve the readability of the questions and enhance the data quality.

The data collection process followed standard procedures. In particular, the cover letters that accompanied the surveys clarified the general purpose of the study, assured participants of complete confidentiality, and mentioned that their participation was entirely voluntary, that no individual-level data would ever be made public, and that only aggregate information would be available to people outside the research team. Participants were explicitly told that there were no correct or incorrect answers, it was normal that different respondents would give varied answers to the questions, and it was critical they answered the questions as honestly as possible all features that reduce concerns about social desirability bias (Spector, 2006). The letter included contact information for a member of the research team, in case participants had questions or wished to share their feedback. Finally, respondents could withdraw from the study at any point.

From the 250 distributed surveys, we received 173 completed responses (rate $=69 \%$ ). Among the respondents, $40 \%$ were women, $58 \%$ were younger than 40 years, their average tenure with the organization was about 3 years, and $34 \%$ had supervisory responsibilities.

\section{Measures}

The four focal constructs were measured with items that have been validated in previous studies, using seven-point Likert scales, ranging from 1 ('strongly disagree') to 7 ('strongly agree'). Table 1 details the items for each of the individual constructs.

\section{Organizational citizenship behaviour}

To measure employees' OCB, we relied on a four-item scale, drawn from previous research (De Cremer, Mayer, van Dijke, Schouten, \& Bardes, 2009). These items captured the extent to which employees engage in voluntary behaviours targeted at improving their organization's well-being, such as 'If necessary, I am prepared to work overtime' and 'I undertake voluntary action to protect the company from potential problems' (Cronbach's $\alpha=.78$ ).

Our reliance on single-respondent, self-reported data to assess the study variables, including the dependent variable, may constitute an empirical weakness, though a recent meta-analysis indicates small differences between self- and other-rated measures of OCB (Carpenter, Berry, \& Houston, 2014). Moreover, people who undertake OCB arguably may provide more valuable insights into their own voluntary efforts, whereas other potential informants (e.g., supervisors, 
Table 1. Constructs and measurement items

\begin{tabular}{|c|c|c|}
\hline & $\begin{array}{l}\text { Factor } \\
\text { loading }\end{array}$ & $t$-Value \\
\hline \multicolumn{3}{|l|}{ Organizational citizenship behaviour } \\
\hline I undertake action to protect the company from potential problems & $.597^{\mathrm{a}}$ & - \\
\hline I have a cooperative relationship with my boss and others in the company & .692 & $6.881^{\star \star \star}$ \\
\hline If necessary, I am prepared to work overtime & .728 & $7.106^{\star \star \star}$ \\
\hline $\begin{array}{l}\text { I develop the necessary skills and knowledge that are of benefit to my } \\
\text { organization. }\end{array}$ & .726 & $7.093^{\star \star \star}$ \\
\hline \multicolumn{3}{|l|}{ Role ambiguity (reversed coded) } \\
\hline I know exactly what is expected of me & .718 & $11.77^{\star \star \star}$ \\
\hline I know that I have divided my time properly & .619 & $9.390^{\star \star *}$ \\
\hline Explanation is clear of what has to be done & .814 & $14.766^{\star \star \star}$ \\
\hline I feel certain about how much authority I have & .816 & $14.844^{\star \star \star}$ \\
\hline I know what my responsibilities are & .935 & $2.305^{\star \star \star}$ \\
\hline Clear, planned goals and objectives exist for my job & $.906^{\mathrm{a}}$ & -- \\
\hline \multicolumn{3}{|l|}{ Political skill } \\
\hline I understand people well & $.694^{\mathrm{a}}$ & -- \\
\hline I find it easy to envision myself in the position of others & .523 & $7.319^{\star \star \star}$ \\
\hline I am able to make most people feel comfortable and at ease around me & .806 & $9.513^{\star \star \star}$ \\
\hline I am good at getting others to respond positively to me & .845 & $9.88^{\star \star \star}$ \\
\hline It is easy for me to develop good rapport with most people & .798 & $9.424^{\star \star *}$ \\
\hline I usually try to find common ground with others & .526 & $6.392^{\star \star \star}$ \\
\hline \multicolumn{3}{|l|}{ Organizational identification } \\
\hline When someone criticizes my organization, it feels like a personal insult & .429 & $3.282^{\star \star \star}$ \\
\hline I am very interested in what others think about my organization & .473 & $3.411^{\star \star \star}$ \\
\hline Organization's successes are my successes & .720 & $3.821^{\star \star \star}$ \\
\hline When someone praises my organization, it feels like a personal compliment & .862 & $3.868^{\star \star *}$ \\
\hline If a story in the media criticizes my organization, I would feel embarrassed & $.321^{\mathrm{a}}$ & -- \\
\hline
\end{tabular}

anitial loading was fixed to 1 to set the scale of the construct. ${ }^{\star \star *} p<.001$.

peers) may only have partial insights into how much personal energy employees invest in such activities (Chan, 2009). Similarly, employees may undertake voluntary work behaviours toward some supervisors or peers but not others, so other-rated measures may underestimate the actual amount of OCB (e.g., Harris and Schaubroeck, 1988; Organ, Podsakoff, and MacKenzie, 2006). Finally, when self-reports are appropriate, concerns about common method bias tend to be mitigated (Conway and Lance, 2010).

\section{Role ambiguity}

We applied a six-item, reverse-coded scale, used in prior research (De Clercq \& Belausteguigoitia, 2017b; Fried \& Tiegs, 1995), to assess employees' beliefs about the presence of unclear role descriptions. Sample items were, 'I know exactly what is expected of me' and 'Explanation is clear of what has to be done' (Cronbach's $\alpha=.92$ ). 


\section{Political skill}

We applied a six-item scale of political skill (Perrewé et al., 2005) to measure employees' social competencies and associated abilities to understand and influence their organization's internal functioning. For example, respondents indicated whether 'I am good at getting others to respond positively to me', 'I usually try to find common ground with others', and 'It is easy for me to develop good rapport with most people' (Cronbach's $\alpha=.85$ ).

\section{Organizational identification}

To assess the extent to which employees feel a strong sense of belonging to their employer, we used a five-item scale of organizational identification (Brammer, He, \& Mellahi, 2015). For example, employees rated 'When someone praises my organization, it feels like a personal compliment', 'When someone criticizes my organization, it feels like a personal insult', and 'Organization's successes are my successes' (Cronbach's $\alpha=.71$ ).

\section{Control variables}

We controlled for employees' gender $(1=$ female $)$, age $(1=<20$ years, $2=20-29$ years, $3=30-39$ years, $4=40-49$ years, $5=50-59$ years, $6=60$ years or older $)$, organizational tenure $(1=<1$ year, $2=1-2$ years, $3=3-5$ years, $4=6-10$ years, $5=11-20$ years, $6=$ more than 20 years), and job level $(1=$ had supervisory responsibilities) to account for alternative possible explanations of employees' engagement in OCB.

We assessed the validity of the study's focal constructs with a four-factor measurement model and confirmatory factor analysis (CFA) (Anderson \& Gerbing, 1988). The model exhibited adequate fit: $\chi_{(181)}^{2}=335.33$, Tucker-Lewis index $=.91$, confirmatory fit index $=.92$ and root mean squared error of approximation $=.07$. In support of convergent validity, the four constructs all featured strongly significant factor loadings for the respective items $(p<.001$, Table 1 , Gerbing and Anderson, 1988). We also found support for the presence of discriminant validity; for the six pairs generated from the four constructs, the differences in the chi-square values of a constrained model (correlation between constructs set to 1 ) versus an unconstrained model (correlation between constructs set free) were significant for each pair $\left(\Delta \chi_{(1)}^{2}>.3 .84\right)$ (Anderson \& Gerbing, 1988).

We performed two tests to assess the possibility of common method bias. First, according to Harman's one-factor test (Podsakoff \& Organ, 1986), if common method bias were a significant issue, a single factor that included all four constructs - role ambiguity, political skill, organizational identification and OCB - would account for most of the variance in the data. The first factor explained only $38 \%$ of the variance, so common method bias did not seem to be a major concern. Second, a CFA in which each item of the four focal constructs loaded on a single factor generated a significantly worse fit than that of the aforementioned four-factor model $\left(\Delta \chi^{2}(8)=\right.$ 472.70, $p<.001$ ) (Lattin, Carroll, \& Green, 2003). In addition, common method bias is less of an issue for models that contain complex moderating effects because it is difficult for respondents to figure out these effects and adjust their responses to them (Brockner, Siegel, Daly, Tyler, \& Martin, 1997; De Clercq, Thongpapanl, \& Dimov, 2009; Simons \& Peterson, 2000). Thus, concerns about the use of a common respondent in our study are minimal.

\section{Results}

Table 2 reports the zero-order correlations and descriptive statistics, and Table 3 provides the results of the hierarchical regression analyses. Model 1 included the control variables, and Model 2 added role ambiguity and the two moderators (political skill and organizational identification). Then Models 3 and 4 included the role ambiguity $\times$ political skill and role ambiguity $\times$ organizational identification interaction terms, respectively. It is appropriate to add multiple interaction terms to different equations because their simultaneous inclusion into a single model can mask true moderating effects (Aiken \& West, 1991; Covin, Green, \& Slevin, 2006; 
Table 2. Correlation table and descriptive statistics

\begin{tabular}{|c|c|c|c|c|c|c|c|c|}
\hline & 1 & 2 & 3 & 4 & 5 & 6 & 7 & 8 \\
\hline \multicolumn{9}{|l|}{$\begin{array}{l}\text { 1. Organizational citizenship } \\
\text { behaviour }\end{array}$} \\
\hline 2. Role ambiguity & $-.593^{\star \star}$ & & & & & & & \\
\hline 3. Political skill & $.547^{\star \star}$ & $-.509^{\star \star}$ & & & & & & \\
\hline 4. Organizational identification & $.360^{\star *}$ & $-.396^{\star \star}$ & $.333^{\star *}$ & & & & & \\
\hline 5. Gender ( $1=$ female $)$ & -.118 & -.026 & -.081 & -.107 & & & & \\
\hline 6. Age & .041 & -.141 & -.014 & .105 & $-.180^{\star}$ & & & \\
\hline 7. Organizational tenure & -.008 & -.116 & -.085 & .101 & -.113 & $.565^{\star \star}$ & & \\
\hline 8. Job level & $.245^{\star *}$ & $-.154^{\star}$ & $.163^{\star}$ & $.214^{\star *}$ & $-.262^{\star \star}$ & $.275^{\star \star}$ & .135 & \\
\hline Mean & 5.840 & 2.013 & 5.436 & 5.346 & .399 & 3.353 & 3.185 & .341 \\
\hline Standard deviation & .923 & .983 & .793 & 1.019 & .491 & 1.077 & 1.544 & .475 \\
\hline
\end{tabular}

Notes: $N=173$.

${ }^{\star *} p<.01 ;{ }^{*} p<.05$.

Table 3. Regression results (dependent variable: organizational citizenship behaviour)

\begin{tabular}{|c|c|c|c|c|c|}
\hline & Model 1 & Model 2 & Model 3 & Model 4 & Model 5 \\
\hline Gender ( 1 = female) & -.117 & -.150 & $-.209^{+}$ & $-.198^{+}$ & $-.229^{\star}$ \\
\hline Age & -.011 & -.039 & -.001 & -.015 & -.018 \\
\hline Organizational tenure & -.024 & -.023 & -.032 & -.032 & -.023 \\
\hline Job level & $.460^{\star \star}$ & $.223^{+}$ & $.215^{+}$ & $.215^{+}$ & $.213+$ \\
\hline $\mathrm{H}_{1}$ : Role ambiguity & & $-.389^{\star \star \star}$ & $-.288^{\star \star \star}$ & $-.339 * \star \star$ & $-.265^{\star \star \star}$ \\
\hline Political skill & & $.327^{\star \star \star}$ & $.213^{*}$ & $.264^{\star \star}$ & $.226^{\star \star}$ \\
\hline Organizational identification & & .071 & .056 & .065 & $.097^{+}$ \\
\hline $\mathrm{H}_{2}$ : Role ambiguity $\times$ political skill & & & $.118^{\star \star \star}$ & & $.163^{\star \star *}$ \\
\hline $\begin{array}{l}\mathrm{H}_{3}: \text { Role ambiguity } \times \text { organizational } \\
\quad \text { identification }\end{array}$ & & & & $.093^{\star \star}$ & $.120^{+}$ \\
\hline Organizational identification $\times$ political skill & & & & & $-.140^{+}$ \\
\hline $\begin{array}{l}\mathrm{H}_{4}: \text { Role ambiguity } \times \text { organizational } \\
\text { identification } \times \text { political skill }\end{array}$ & & & & & $.075^{\star \star \star}$ \\
\hline$R^{2}$ & .065 & .463 & .503 & .485 & .540 \\
\hline$R^{2}$ change & & $.398^{\star \star \star}$ & $.040^{\star \star \star}$ & $.022^{\star \star}$ & $.077^{\star \star \star}$ \\
\hline
\end{tabular}

Notes: $N=173$. Unstandardized regression coefficients (and standard errors, in parentheses) are reported.

${ }_{\star \star \star *} p<.001 ;{ }^{* *} p<.01 ;{ }^{*} p<.05 ;{ }^{+} p<.10$ (two-tailed tests).

Zahra \& Hayton, 2008). Finally, Model 5 featured the three-way interaction term (role ambiguity $\times$ organizational identification $\times$ political skill), together with the three constitutive two-way interactions (Aiken \& West, 1991). Following established practice, we mean-centred the product terms in the two- and three-way interactions (Aiken \& West, 1991).

Consistent with our baseline argument that hardships caused by unclear role descriptions steer employees away from undertaking voluntary work activities, in Model 2 role ambiguity related 


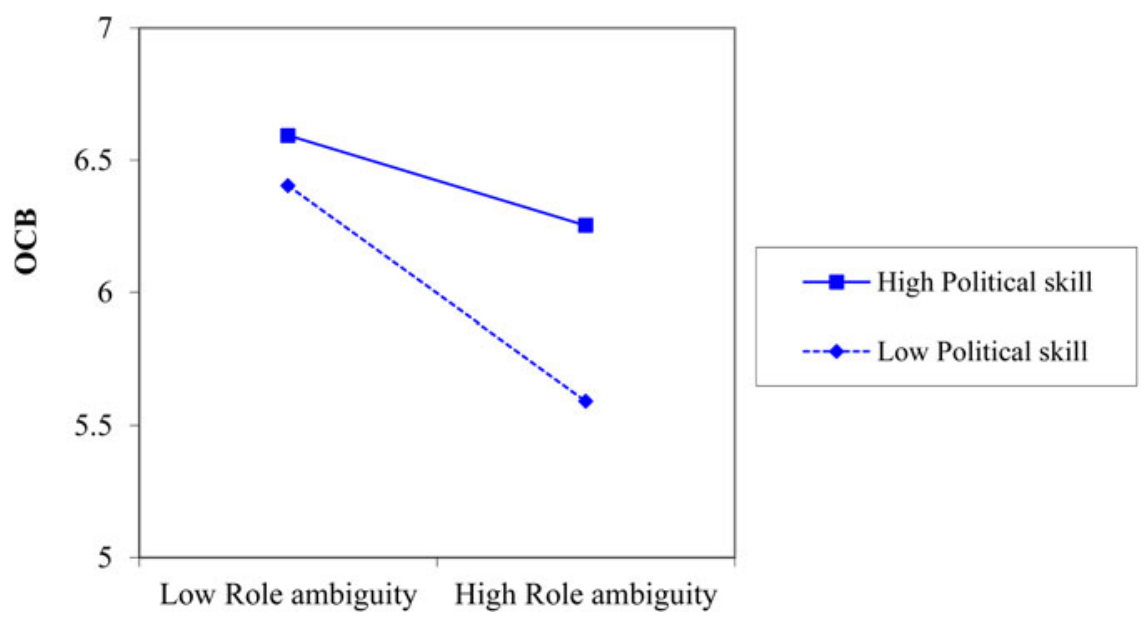

Figure 2. Moderating effect of political skill on the relationship between role ambiguity and organizational citizenship behaviour.

negatively to OCB $(\beta=-.389, p<.001)$, in support of Hypothesis 1 . In relationships that were not part of our conceptual framework, Model 2 also revealed a direct positive relationship of political skill $(\beta=.327 p<.001)$ but no significant relationship of organizational identification $(\beta=.071$, $n s)$ with OCB. In addition, Models 3-4 supported the hypothesized buffering effects of political skill $(\beta=.118, p<.001)$ and organizational identification $(\beta=.093, p<.01)$ on the negative relationship between role ambiguity and OCB. The likelihood that employees' beliefs about unclear role descriptions undermine their OCB was lower when they could draw from their political skill (Hypothesis 2) and strong sense of organizational identification (Hypothesis 3). We graph these buffering effects in Figures 2 and 3, with corresponding slope analyses at one standard deviation above and below the means of the moderators (Aiken \& West, 1991). The results indicated that the negative relationship between role ambiguity and OCB was very strongly significant when political skill $(\beta=-.406, p<.001)$ and organizational identification $(\beta=-.432, p<.001)$ were low, but it diminished in significance at high levels of these moderators $(\beta=-.170, p<.10$, and $\beta=$ $-246, p<.01$, respectively), in support of Hypotheses 2 and 3.

We also found a significant three-way interaction among role ambiguity, organizational identification, and political skill in Model $5(\beta=.075, p<.001)$. To clarify the nature of this interaction, we plotted the moderating effect of organizational identification on the relationship between role ambiguity and $\mathrm{OCB}$ at high versus low levels of political skill in Figure 4. At high levels of political skill (Panel A), the interaction plot showed a pattern consistent with that in Figure 3: Role ambiguity strongly reduced OCB when organizational identification was low, which was not the case when organizational identification was high. However, at low levels of political skill (Panel B), the two lines were almost parallel, indicating the absence of a buffering effect of organizational identification on the relationship between role ambiguity and organizational identification when employees lacked political competencies. Following Dawson and Richter (2006), we also assessed whether the slope differences were significant. Although the slope difference in Figure 4, Panel A, was significant $(t=2.758, p<.01)$, it was not in Figure 4, Panel B $(t=.636, n s)$. These patterns were consistent with Hypothesis 4 : When employees can draw from relevant political competencies, the beneficial role of organizational identification in reducing the likelihood that role ambiguity escalates into lower OCB is particularly prominent (Panel A). However, when their political skill is low, the rate at which OCB diminishes in response to increasing levels of role ambiguity is virtually the same at high and low levels of organizational identification (Panel B). 


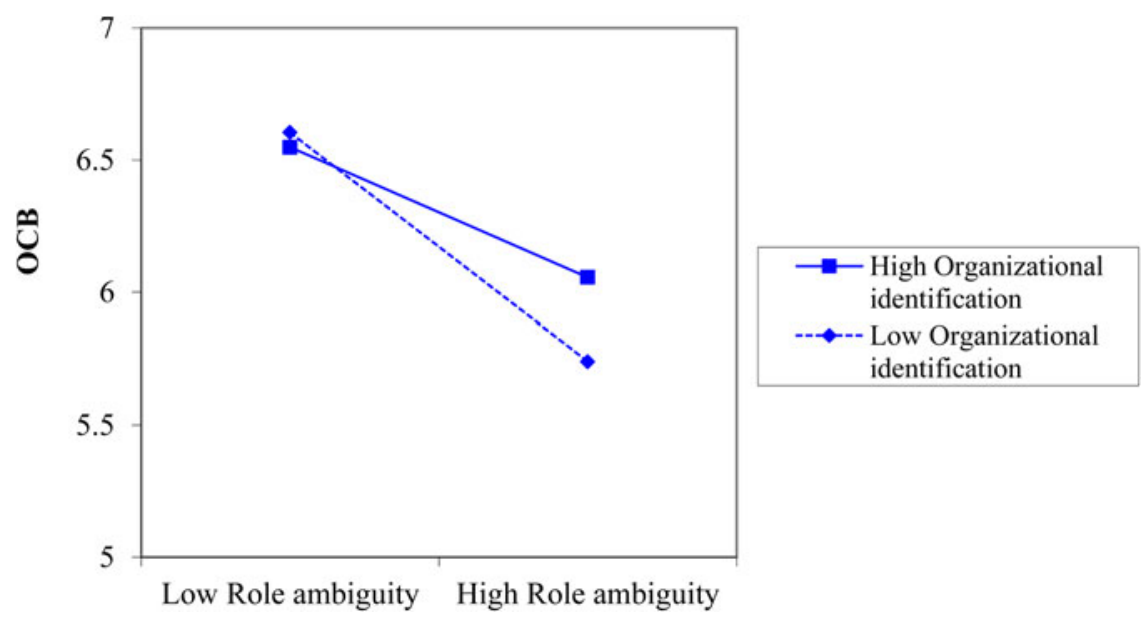

Figure 3. Moderating effect of organizational identification on the relationship between role ambiguity and organizational citizenship behaviour.

\section{Discussion}

This study extends previous research by examining the concurrent effects of role ambiguity and two critical personal resources, political skill, and organizational identification, for predicting OCB. The relative lack of attention to this topic is somewhat surprising, in light of the recognition that spending time on voluntary work activities usurps significant energy (Podsakoff et al., 2009) and can be challenging for resource-deprived employees who are exposed to ambiguous work conditions that already make it difficult to complete their job tasks (Schmidt et al., 2014; Showail, McClean Parks, \& Smith, 2013). With a basis in COR theory, this study predicts how role ambiguity might discourage OCB but also how avoiding OCB in response to resource depletion due to role ambiguity is less likely to materialize to the extent that employees can draw from relevant personal resources that enhance either their ability (political skill) or their motivation (organizational identification) to maintain some OCB in this adverse work situation (Hobfoll \& Shirom, 2000).

The direct negative relationship between role ambiguity and OCB mirrors findings from previous studies about the detrimental effect of role stress on positive work outcomes such as job satisfaction (Kawai \& Mohr, 2015) or work productivity (Zhou et al., 2016). This negative relationship stems from the energy resource depletion that employees experience when they lack clear explanations about their job responsibilities (Au \& Ahmed, 2016; Zhou et al., 2016), leaving them without sufficient resources to allocate to voluntary work behaviours (Hobfoll, 2001). Despite this negative relationship, as revealed in this study, previous research indicates that this connection might not be automatic because vague job descriptions also could give employees more leeway in terms of the work activities they decide to undertake (Bernard, Osmonbekov, \& McKee, 2011; Rizzo, House, \& Lirtzman, 1970). For example, if their job responsibilities are unclear, the boundary between formal job duties and voluntary behaviours gets blurred, resulting in greater perceived role breadth, which might increase employees' felt responsibility to dedicate some of their time to discretionary work behaviours (Fuller, Marler, \& Hester, 2006; Morrison, 1994). Because the energy depletion associated with role ambiguity might not always lead to negative work outcomes, a continued need exists to investigate which contingency factors can contain its harmful effects (De Clercq, Haq, \& Azeem, 2019; Eatough et al., 2011; Schmidt et al., 2014). We have addressed this issue by investigating the moderating roles of two key personal resources: political skill and organizational identification. 
(a) : High political skill

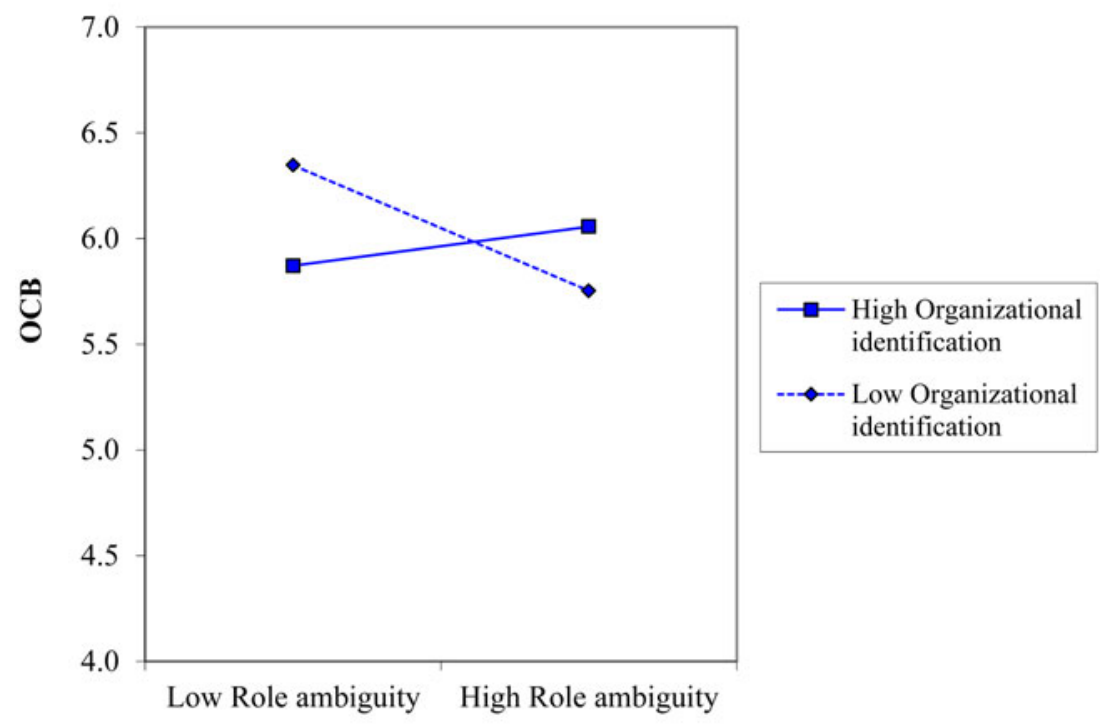

(b): Low political skill

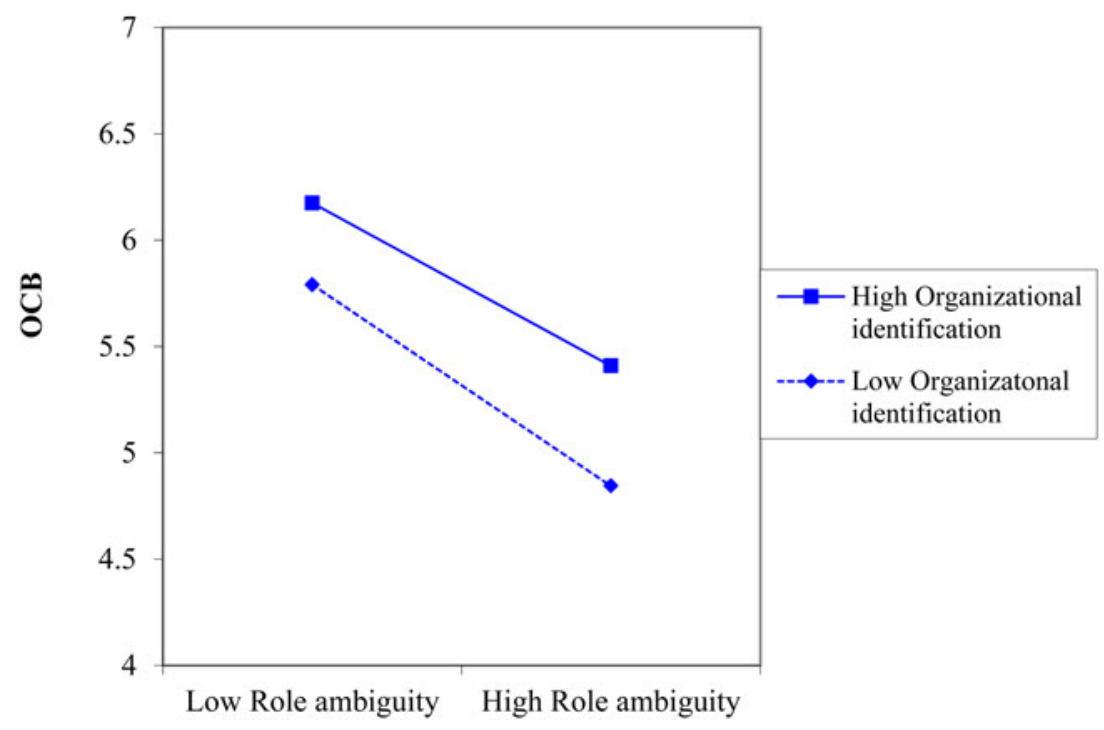

Figure 4. Three-way interaction effect of organizational identification on the role ambiguity-organizational citizenship behaviour relationship. A: High political skill. B: Low political skill.

The empirical results confirm the theorized buffering roles of these resources: The translation of role ambiguity into diminished OCB is less likely among employees who are politically skilled and strongly identify with their employing organization. Notably, these buffering roles speak to the incremental role of role ambiguity in diminishing $\mathrm{OCB}$, so this study provides organizations with insights into the conditions in which information deficiencies about job responsibilities are less likely to hinder voluntary work behaviours. Empirically, these buffering roles are manifest as slope differences that appear at various levels of the moderators. The interaction graphs in Figures 2 and 3, 
along with the associated simple slope analyses, reveal that increasing levels of role ambiguity diminish OCB to a lesser extent when employees possess political competencies that increase their understanding and influence over their organization's internal functioning, as well as when they feel a strong sense of identification with their employer. Alternatively, the frustration that their job duties are not clearly outlined undermines employees' OCB more if the employees have limited access to such personal resources.

The buffering role of organizational identification is particularly insightful in light of the lack of a direct significant relationship between this personal resource and OCB $(\beta=.071, n s$, Model 2, Table 3$)$. That is, we find a significant positive correlation between organizational identification and OCB $(r=.360, p<.01$, Table 2$)$, but employees' sense of organizational identification does not spur OCB beyond the resource-draining effect of role ambiguity. This finding might reflect the country context - the stress invoked by unclear job descriptions may seem particularly problematic in an uncertainty-avoidant country such as Mexico (Hofstede, Hofstede, \& Minkov, 2010) - but the findings also underscore an indirect beneficial role of organizational identification: It prevents ruminations about job-related information shortages from escalating into a reluctance to engage in OCB.

This study's focus on the specific contingencies of political skill and organizational identification also underscores how role ambiguity might thwart OCB, due to both ability and motivation factors. Employees who are stressed or frustrated by a lack of clarity about their job responsibilities may feel incapable of combining formally prescribed job duties with additional voluntary activities (Showail, McClean Parks, \& Smith, 2013; Singh, Suar, \& Leiter, 2012), and they also might exhibit less motivation to undertake voluntary activities that otherwise could benefit their organization (O’Driscoll \& Beehr, 2000; Zhang, Tsingan, \& Zhang, 2013). In turn, the escalation of role ambiguity into reduced OCB can be contained more easily to the extent that employees have access to personal resources that enhance either their ability to combine formal job duties with $\mathrm{OCB}$ in the presence of role ambiguity (i.e., political skill) or their motivation to do so (i.e., organizational identification).

Furthermore, this study adds to extant research by detailing the interdependent, complementary roles of different personal resources in buffering the negative consequences of role ambiguity. The usefulness of organizational identification for countering the harmful effect of role ambiguity is particularly high when employees can draw from relevant political skills. In contrast, a strong sense of belonging has less incremental importance for mitigating the conversion of role ambiguity into diminished OCB among less politically skilled employees. With this explicit acknowledgment of the interrelated, reinforcing effects of these two personal resources for mitigating the translation of role ambiguity into reduced OCB, we find support for the COR logic of positive resource spirals, which is often theorized but rarely tested empirically (Hobfoll, 2001; Hobfoll, Halbesleben, Neveu, \& Westman, 2018).

Formally, this study shows that organizational identification influences employees' desire to maintain some levels of OCB in the presence of resource-draining role ambiguity, and the functional role of this personal resource is even stronger to the extent that employees also have the ability to channel their desire into positive work behaviours, as informed by their political skill (Hobfoll, 2011). As a key insight, this study accordingly indicates that organizations worried about how adverse job situations might prevent employees from engaging in OCB should simultaneously invest in building their political skills and stimulating their organizational identification, rather than investing in encouraging the expansion of only one of these personal resources.

Overall, these buffering roles of political skill and organizational identification, as revealed in a study situated in Mexico, are consistent with COR theory: The relative importance of adverse, resource-draining work conditions for diminishing positive work behaviours decreases in the presence of relevant personal resources (Hobfoll, 2001; Hobfoll \& Shirom, 2000). These results thus establish a more complete understanding of when role ambiguity is likely to reduce employees' propensity to go out of their way to perform OCB, or not, according to the distinct and combined mitigating influences of two personal resources. 


\section{Practical implications}

Organizational decision makers must acknowledge that employees might be reluctant to take on additional voluntary activities if they do not know what their formal job responsibilities are. They also are responsible to identify employees who might be frustrated because they perceive that they have not received sufficient information about their job roles; the employees likely are not keen to share these frustrations, which might signal their lack of initiative or a perception that they do not know what they are doing (Schmidt et al., 2014). Organizations thus must be proactive and find employees who suffer from unclear role descriptions, then resolve the possible causes of this situation, such as a lack of formalized work procedures or inadequate integration mechanisms for newcomers.

In addition to this general recommendation to avoid frustrating employees with insufficient information, this study offers insights for organizations that ultimately cannot provide detailed role descriptions for each employee, whether because the work is complex, the company is really large, or external pressures demand flexibility and constant change (Kahn et al., 1964). Political skills among employees represent critical mechanisms for reducing the risk that role ambiguity leads to a reluctance to engage in OCB. If some role ambiguity cannot be avoided, employees who can rely on adequate social competencies still can protect themselves against the resulting hardships, leaving them with sufficient energy resources to undertake voluntary activities that can enhance their organization's well-being. To spur employees' political skill, organizations could encourage them to develop and hone skills for coping with workplace adversity, as well as showcase positive role models who successfully assist their organization on a voluntary basis, even when faced with unclear role descriptions.

Organizations also might work to stimulate positive emotions and a strong organizational identification among employees. For example, nurturing strong relationships with organizational peers might leave employees more comfortable about sharing personal concerns about their job situation, while also sustaining an organizational culture that stimulates a collective identity instead of a focus on personal interests (Ashforth, Harrison, \& Gorley, 2008). Such measures can spur informal knowledge-sharing routines among employees, which diminish the hardships associated with unclear role descriptions (Schmidt et al., 2014). But if employees lack a strong emotional connection with their organization, they might be less forgiving of unfavourable work conditions and less prone to reach out to or learn from other organizational members. The recruitment and training of employees accordingly should address whether they are willing to prioritize their organization's well-being over their personal interests so that they can reserve some of their time for voluntary activities, even when their work conditions are challenging.

\section{Limitations and future research}

This study has some shortcomings, which suggest avenues for continued research. First, the crosssectional research design may raise concerns about reverse causality, if employees derive personal meaning from undertaking voluntary work activities, which generates more positive perceptions of their work environment, regardless of the amount of information available about their job responsibilities (Podsakoff et al., 2009). Our hypotheses are anchored in the well-established COR theory, which suggests a causal negative link between a resource-draining work condition such as role ambiguity and propensity to undertake energy-consuming efforts (Hobfoll, 1989), but further research that applies longitudinal designs could explicitly examine the causal processes that link role ambiguity with $\mathrm{OCB}$, as well as the contingency conditions that influence this process. Similarly, we argued that employees' experience of role ambiguity reduces both their ability and their motivation to dedicate substantial efforts to voluntary activities. Studies could measure these mechanisms directly to investigate, for example, whether the ability- or motivation-based arguments are more salient.

Second, the focus on the contingent roles of political skill and organizational identification is relevant and insightful - in that these two personal resources complement each other by 
capturing employees' ability and motivation, respectively, to undertake discretionary work behaviours in the presence of role ambiguity - yet it excludes other personal factors that might buffer the negative relationship between role ambiguity and OCB too. For example, the likelihood that unclear role descriptions escalate into a lower propensity to undertake voluntary work behaviours could be reduced by employees' passion for work (Baum \& Locke, 2004), proactive personality (Li, Liang, \& Crant, 2010), or creative self-efficacy (Tierney \& Farmer, 2002). Organizational factors might serve as buffers too, such as when organizational decision-making procedures are perceived as fair (Colquitt, Conlon, Wesson, Porter, \& Ng, 2001), the organizational climate encourages voluntarism (Chen, Takeuchi, \& Shum, 2013), or training programs stimulate employees to go the extra mile and contribute to their organization's well-being voluntarily (Organ, 1988).

Third, our reliance on single-respondent data from one organization might limit the generalizability of the results. Despite meta-analytical evidence of the consistency of self- and otherratings of voluntary work behaviours (Carpenter, Berry, \& Houston, 2014), future research still could benefit from using multirespondent designs. Further, our single-organization design offers a clear advantage, in that it allows us to control for organization-wide factors (e.g., an organizational climate that supports voluntarism), but it would be useful to test the conceptual framework across different organizations, particularly those operating in different industries. Our theoretical arguments were not industry specific, but with this research design, we could not investigate potentially relevant industry factors, such as the level of competitive intensity or dynamism in external markets (Jaworski \& Kohli, 1993; Porter, 1996). High levels of market turbulence, for example, might help employees realize why their employer cannot explicate the job responsibilities of each employee (Kahn et al., 1964), which could limit the negative effects of this adverse work condition on their willingness to undertake OCB. Further research should investigate the conceptual framework across different industries.

Fourth, another potential empirical weakness pertains to the reliability values for two focal constructs (OCB and organizational identification). The values exceed the well-established benchmark of .70 (Nunnally, 1978), but they admittedly are not very high. Previous research suggests that reliability values should be interpreted in relation to values found in similar empirical settings (McCrae, Kurtz, Yamagata, \& Terracciano, 2011); in particular, the reliabilities of personal characteristic scales developed in Western settings tend to be lower in less developed countries (e.g., Bouckenooghe, 2012; Kwantes, 2003; Yilmaz, Ozer, and Gunluk, 2014). Moreover, low reliability values attenuate regression estimates (Schmitt, 1996), so studies that find significant effects, despite relatively low reliabilities, offer more conservative statistical tests of the hypothesized relationships. Nonetheless, we acknowledge these relatively low-reliability values, which constitute a weakness of this study.

Fifth, our theoretical arguments were not country-specific, yet cultural factors may be relevant, considering that we conducted our study in a specific, transformational economy. Mexican culture is characterized by high levels of uncertainty avoidance (Hofstede, Hofstede, \& Minkov, 2010), so employees may be particularly sensitive to the hardships of unclear job role descriptions. In turn, the usefulness of personal resources for mitigating the harmful effects of role ambiguity could be more prevalent in our study than in more risk-oriented country contexts. The collectivism that marks Mexican culture (Hofstede, Hofstede, \& Minkov, 2010) also implies that employees might be more inclined to engage in voluntary work behaviours, regardless of their work circumstances. Comparisons across cultures, especially different transformational economies, could clarify the relative instrumentality of role ambiguity for diminishing employees' propensity to carry out $\mathrm{OCB}$, as well as the potency of different moderators in this process.

\section{Conclusion}

This study adds to previous research by addressing when employees' role ambiguity is less likely to leave them reluctant to engage in OCB. The likelihood that concerns about incomplete role 
descriptions escalate into diminished voluntary work activities decreases to the extent that employees can rely on both relevant political skills and a strong organizational identification. These personal resources fuel employees' ability and motivation to take on voluntary behaviours in addition to their regular job tasks, even when they confront uncertainties about their job responsibilities. We hope this article functions as a catalyst for continued studies of how organizations can promote positive work behaviours among their employee bases, despite the presence of unfavourable work circumstances.

Acknowledgements. We sincerely thank the editors and reviewers for their constructive feedback on this article.

Author ORCIDs. (D) Dirk De Clercq 0000-0003-1476-2965.

\section{References}

Abbas, M., Raja, U., Darr, W., \& Bouckenooghe, D. (2014). Combined effects of perceived politics and psychological capital on job satisfaction, turnover intentions, and performance. Journal of Management, 40, 1813-1183.

Aiken, L. S., \& West, S. G. (1991). Multiple regression: Testing and interpreting interactions. Newbury Park, CA: Sage.

Anderson, J. C., \& Gerbing, D. W. (1988). Structural equation modeling in practice: A review and recommended two-step approach. Psychology Bulletin, 1033, 411-423.

Arthaud-Day, M. L., Rode, J. C., \& Turnley, W. H. (2012). Direct and contextual effects of individual values on organizational citizenship behavior in teams. Journal of Applied Psychology, 97, 792-807.

Ashforth, B. E., Harrison, S. H., \& Gorley, K. G. (2008). Identification in organizations: An examination of four fundamental questions. Journal of Management, 34, 325-374.

Au, W. C., \& Ahmed, P. K. (2016). Relationships between superior support, work role stressors and work-life experience. Personnel Review, 45, 782-803.

Bachrach, D. G., Powell, B. C., Collins, B. J., \& Richey, R. G. (2006). Effects of task interdependence on the relationship between helping behavior and group performance. Journal of Applied Psychology, 91, 1396-1405.

Baum, J. R., \& Locke, E. A. (2004). The relationship of entrepreneurial traits, skill, and motivation to subsequent venture growth. Journal of Applied Psychology, 89, 587-598.

Bernard, E., Osmonbekov, T., \& McKee, D. (2011). Customer learning orientation in public sector organizations. Journal of Nonprofit \& Public Sector Marketing, 23, 158-180.

Bing, M. N., Davison, H., Minor, I., Novicevic, M. M., \& Frink, D. D. (2011). The prediction of task and contextual performance by political skill: A meta-analysis and moderator test. Journal of Vocational Behavior, 79, 563-577.

Borman, W. C., \& Motowidlo, S. J. (1993). Expanding the criterion domain to include elements of contextual performance. In N. Schmitt \& W. C. Borman (Eds.), Personnel selection in organizations (pp. 71-98). San Francisco: Jossey-Bass.

Bouckenooghe, D. (2012). The role of organizational politics, contextual resources, and formal communication on change recipients' affective commitment to change: A multilevel study. European Journal of Work and Organizational Psychology, 21, 575-602.

Brammer, S., He, H., \& Mellahi, K. (2015). Corporate social responsibility, employee organizational identification, and creative effort: The moderating impact of corporate ability. Group \& Organization Management, 40, 323-352.

Brickson, S. L. (2013). Athletes, best friends, and social activists: An integrative model accounting for the role of identity in organizational identification. Organization Science, 24, 226-245.

Brislin, R. W., Lonner, W., \& Thorndike, R. M. (1973). Cross-cultural research methods. New York: John Wiley \& Sons.

Brockner, J., Siegel, P. A., Daly, J. P., Tyler, T., \& Martin, C. (1997). When trust matters: The moderating effect of outcome favourability. Administrative Science Quarterly, 42, 558-583.

Carpenter, N. C., Berry, C. M., \& Houston, L. (2014). A meta-analytic comparison of self reported and other-reported organizational citizenship behavior. Journal of Organizational Behavior, 35, 547-574.

Chan, D. (2009). So why ask me? Are self-report data really that bad? In C. E. Lance, \& R. J. Vandenberg (Eds.), Statistical and methodological myths and urban legends: Doctrine, verity and fable in the organizational and social sciences (pp. 309-336). New York, NY: Routledge.

Chen, M.-F., Lin, C.-P., \& Lien, G.-Y. (2011). Modelling job stress as a mediating role in predicting turnover intention. Service Industries Journal, 31, 1327-1345.

Chen, Z., Takeuchi, R., \& Shum, C. (2013). A social information processing perspective of coworker influence on a focal employee. Organization Science, 24, 1618-1639.

Colquitt, J. A., Conlon, D. E., Wesson, M. J., Porter, C. O. L. H., \& Ng, K. Y. (2001). Justice at the millennium: A meta-analytic review of 25 years of organizational justice research. Journal of Applied Psychology, 86, 425-445.

Conway, J. M., \& Lance, C. E. (2010). What reviewers should expect from authors regarding common method bias in organizational research. Journal of Business Psychology, 25, 325-334. 
Covin, J. G., Green, K. M., \& Slevin, D. P. (2006). Strategic process effects on the entrepreneurial orientation-sales growth rate relationship. Entrepreneurship Theory \& Practice, 30, 57-81.

Curran, T. M., \& Prottas, D. J. (2017). Role stressors, engagement and work behaviours: A study of higher education professional staff. Journal of Higher Education Policy and Management, 39, 642-657.

Dawson, J. F., \& Richter, A. W. (2006). Probing three-way interactions: The development and application of a slope difference test. Journal of Applied Psychology, 91, 917-926.

De Clercq, D., \& Belausteguigoitia, I. (2017a). Mitigating the negative effect of perceived organizational politics on organizational citizenship behavior: Moderating roles of contextual and personal resources. Journal of Management and Organization, 23, 689-708.

De Clercq, D., \& Belausteguigoitia, I. (2017b). Reducing the harmful effect of role ambiguity on turnover intentions: The roles of innovation propensity, goodwill trust, and procedural justice. Personnel Review, 46, 1046-1069.

De Clercq, D., Haq, I. U., \& Azeem, M. U. (2019). Role ambiguity and perceptions of unfair performance appraisals: Mitigating roles of personal resources. Asia Pacific Journal of Human Resources, 57, 150-173.

De Clercq, D., Thongpapanl, N., \& Dimov, D. (2009). When good conflict gets better and bad conflict becomes worse: The role of social capital in the conflict-innovation relationship. Journal of the Academy of Marketing Science, 37, $283-297$.

De Cremer, D., Mayer, D., van Dijke, M., Schouten, B., \& Bardes, M. (2009). When does self-sacrificial leadership motivate prosocial behavior? It depends on followers' prevention focus. Journal of Applied Psychology, 94, 887-899.

Eatough, E. M., Chang, C. H., Miloslavic, S. A., \& Johnson, R. E. (2011). Relationships of role stressors with organizational citizenship behavior: A meta-analysis. Journal of Applied Psychology, 96, 619-632.

Ferris, G. R., Davidson, S. L., \& Perrewé, P. L. (2005). Political skill at work: Impact on work effectiveness. Mountain View, CA: Davies-Black Publishing.

Ferris, G. R., Treadway, D. C., Kolodinsky, R. W., Hochwarter, W. A., Kacmar, C. J., Douglas, C., \& Frink, D. D. (2005). Development and validation of the political skill inventory. Journal of Management, 31, 126-152.

Ferris, G. R., Treadway, D. C., Perrewé, P. L., Brouer, R. L., Douglas, C., \& Lux, S. (2007). Political skill in organizations. Journal of Management, 33, 290-232.

Fried, Y., \& Tiegs, R. (1995). Supervisors' role conflict and role ambiguity differential relations with performance ratings of subordinates and the moderating effect of screening ability. Journal of Applied Psychology, 80, 282-291.

Fuller, J. B., Marler, L. E., \& Hester, K. (2006). Promoting felt responsibility for constructive change and proactive behavior: Exploring aspects of an elaborated model of work design. Journal of Organizational Behavior, 27, 1089-1120.

Gerbing, D. W., \& Anderson, J. C. (1988). An updated paradigm for scale development incorporating unidimensionality and its assessment. Journal of Marketing Research, 25, 186-192.

Harris, M. M., \& Schaubroeck, J. (1988). A meta-analysis of self-supervisor, self-peer, and peer-supervisor ratings. Personnel Psychology, 41, 43-62.

Hobfoll, S. E. (1989). Conservation of resources: A new attempt at conceptualizing stress. American Psychologist, 44, 513-524.

Hobfoll, S. E. (2001). The influence of culture, community, and the nested-self in the stress process: Advancing conservation of resource theory. Applied Psychology: An International Review, 50, 337-369.

Hobfoll, S. E. (2011). Conservation of resource caravans and engaged settings. Journal of Occupational and Organizational Psychology, 84, 116-122.

Hobfoll, S. E., Halbesleben, J., Neveu, J.-P., \& Westman, M. (2018). Conservation of resources in the organizational context: The reality of resources and their consequences. Annual Review of Organizational Psychology and Organizational Behavior, 5, $103-128$.

Hobfoll, S. E., \& Shirom, A. (2000). Conservation of resources theory: Applications to stress and management in the workplace. In R. T. Golembiewski (Ed.), Handbook of organization behavior (2nd ed., pp. 57-81). New York: Dekker.

Hochwarter, W. A., Ferris, G. R., Gavin, M. B., Perrewé, P. L., Hall, A. T., \& Frink, D. D. (2007). Political skill as neutralizer of felt accountability-job tension effects on job performance ratings: A longitudinal investigation. Organizational Behavior and Human Decision Processes, 102, 226-239.

Hodson, R. (2002). Management citizenship behavior and its consequences. Work and Occupations, 29, 64-96.

Hofstede, G. H., Hofstede, G. J., \& Minkov, M. (2010). Cultures and organizations: Software of the mind. Intercultural cooperation and its importance for survival (3rd ed.). New York: McGraw-Hill.

Jaworski, B. J., \& Kohli, A. K. (1993). Market orientation: Antecedents and consequences. Journal of Marketing, 57, 53-70.

Kahn, R., Wolfe, D., Quinn, R., Snoek, J., \& Rosenthal, R. (1964). Organizational stress: Studies in role conflict and ambiguity. New York: Wiley.

Kawai, N., \& Mohr, A. (2015). The contingent effects of role ambiguity and role novelty on expatriates' work-related outcomes. British Journal of Management, 26, 163-181.

Kolodinsky, R. W., Treadway, D. C., \& Ferris, G. R. (2007). Political skill and influence effectiveness: Testing portions of an expanded Ferris and Judge (1991) model. Human Relations, 60, 1747-1777.

Kwantes, C. T. (2003). Organizational citizenship and withdrawal behaviors in the USA and India: Does commitment make a difference? International Journal of Cross Cultural Management, 3, 5-26.

Lattin, J. M., Carroll, J. D., \& Green, P. E. (2003). Analyzing multivariate data. Belmont, CA: Thomson Brooks/Cole.

Lazarus, R. S., \& Folkman, S. (1984). Stress, appraisal, and coping. New York: Springer Publishing Company. 
Li, N., Liang, J., \& Crant, J. M. (2010). The role of proactive personality in job satisfaction and organizational citizenship behavior: A relational perspective. Journal of Applied Psychology, 95, 395-404.

Lievens, F., De Corte, W., \& Schollaert, E. (2008). A closer look at the frame-of-reference effect in personality scale scores and validity. Journal of Applied Psychology, 93, 268-279.

Lin, C.-C., \& Peng, T.-K. (2010). From organizational citizenship behaviour to team performance: The mediation of group cohesion and collective efficacy. Management and Organization Review, 6, 55-75.

Liu, Y., Loi, R., \& Lam, L. W. (2011). Linking organizational identification and employee performance in teams: The moderating role of team-member exchange. International Journal of Human Resource Management, 22, 3187-3201.

Mael, F., \& Ashforth, B. E. (1992). Alumni and their alma mater: A partial test of the reformulated model of organizational identification. Journal of Organizational Behavior, 13, 103-123.

McCrae, R., Kurtz, J. E., Yamagata, S., \& Terracciano, A. (2011). Internal consistency, retest reliability, and their implications for personality scale validity. Personality and Social Psychology Review, 15, 28-50.

Morrison, E. (1994). Role definitions and organizational citizenship behavior: The importance of the employees' perspective. Academy of Management Journal, 37, 1543-1567.

Munyon, T. P., Summers, J. K., Thompson, K. M., \& Ferris, G. R. (2015). Political skill and work outcomes: A theoretical extension, meta-analytic investigation, and agenda for the future. Personnel Psychology, 68, 143-184.

Naseer, S., Raja, U., Syed, F., Donia, M. B. L., \& Darr, W. (2016). Perils of being close to a bad leader in a bad environment: Exploring the combined effects of despotic leadership, leader member exchange, and perceived organizational politics on behaviors. The Leadership Quarterly, 27, 14-33.

Noblet, A. J., McWilliams, J., Teo, S. T., \& Rodwell, J. J. (2006). Work characteristics and employee outcomes in local government. International Journal of Human Resource Management, 17, 1804-1818.

Nunnally, J. C. (1978). Psychometric theory (2nd ed.). New York: McGraw-Hill.

Ocampo, L., Acedillo, V., Bacunador, A. M., Balo, C. C., Lagdameo, Y. J., \& Tupa, N. S. (2018). A historical review of the development of organizational citizenship behavior (OCB) and its implications for the twenty-first century. Personnel Review, 47, 821-862.

O’Driscoll, M., \& Beehr, T. (2000). Moderating effects of perceived control and need for clarity on the relationship between role stressors and employee affective reactions. Journal of Social Psychology, 140, 151-159.

Organ, D. W. (1988). Organizational citizenship behavior: The good soldier syndrome. Lexington, MA: Lexington Books.

Organ, D. W., Podsakoff, P. M., \& MacKenzie, S. B. (2006). Organizational citizenship behavior: Its nature, antecedents, and consequences. Thousand Oaks, CA: Sage.

Ozyilmaz, A., \& Cicek, S. S. (2015). How does servant leadership affect employee attitudes, behaviors, and psychological climates in a for-profit organizational context? Journal of Management and Organization, 21, 263-290.

Paillé, P. (2011). Perceived stressful work, citizenship behaviour and intention to leave the organization in a high turnover environment: Examining the mediating role of job satisfaction. Journal of Management Research, 3, 1-16.

Perrewé, P. L., Zellars, K. L., Rossi, A. M., Ferris, G. R., Kacmar, C. J., Liu, Y., Zinko, R., \& Hochwarter, W. A. (2005). Political skill: An antidote in the role overload-strain relationship. Journal of Occupational Health Psychology, 10, $239-225$.

Podsakoff, N. P., Whiting, S. W., Podsakoff, P. M., \& Blume, B. D. (2009). Individual-and organizational-level consequences of organizational citizenship behaviors: A meta-analysis. Journal of Applied Psychology, 94, 122-141.

Podsakoff, P. M., Ahearne, M., \& MacKenzie, S. B. (1997). Organizational citizenship behavior and the quantity and quality of work group performance. Journal of Applied Psychology, 82(2), 262-227.

Podsakoff, P. M., \& Organ, D. W. (1986). Self-reports in organization research: Problems and prospects. Journal of Management, 12, 532-544.

Pooja, A. A., De Clercq, D., \& Belausteguigoitia, I. (2016). Job stressors and organizational citizenship behavior: The roles of organizational commitment and social interaction. Human Resource Development Quarterly, 27, 373-405.

Porter, M. E. (1996). What is strategy? Harvard Business Review, 74, 61-81.

Priesemuth, M., \& Taylor, R. M. (2016). The more I want, the less I have left to give: The moderating role of psychological entitlement on the relationship between psychological contract violation, depressive mood states, and citizenship behavior. Journal of Organizational Behavior, 37, 967-982.

Quinn, R. W., Spreitzer, G. M., \& Lam, C. F. (2012). Building a sustainable model of human energy in organizations: Exploring the critical role of resources. Academy of Management Annals, 6, 337-396.

Ralston, D. A., Lee, C. H., Perrewé, P. L., Van Deusen, C., Vollmer, G. R., Maignan, I. S. J., \& Wan, P. (2010). A multi-society examination of the impact of psychological resources on stressor-strain relationships. Journal of International Business Studies, 41, 652-667.

Riketta, M. (2005). Organizational identification: A meta-analysis. Journal of Vocational Behavior, 66, 358-384.

Rizzo, J. R., House, R. J., \& Lirtzman, S. I. (1970). Role conflict and ambiguity in complex organizations. Administrative Science Quarterly, 15, 150-163.

Rose, K. (2016). Examining organizational citizenship behavior in the context of human resource development: An integrative review of the literature. Human Resource Development Review, 15, 295-316.

Rurkkhum, S., \& Bartlett, K. R. (2012). The relationship between employee engagement and organizational citizenship behaviour in Thailand. Human Resource Development International, 15, 157-174. 
Russo, M., Guo, L., \& Baruch, Y. (2014). Work attitudes, career success and health: Evidence from China. Journal of Vocational Behavior, 84, 248-258.

Schilpzand, M. C., Martins, L. L., Kirkman, B. L., Lowe, K. B., \& Chen, Z. X. (2013). The relationship between organizational justice and organizational citizenship behaviour: The role of cultural value orientations. Management and Organization Review, 9, 345-374.

Schmidt, S., Roesler, U., Kusserow, T., \& Rau, R. (2014). Uncertainty in the workplace: Examining role ambiguity and role conflict, and their link to depression-a meta-analysis. European Journal of Work and Organizational Psychology, 23, 91-106.

Schmitt, N. (1996). Uses and abuses of coefficient alpha. Psychological Assessment, 8, 350-353.

Shin, Y. (2012). CEO ethical leadership, ethical climate, climate strength, and collective organizational citizenship behavior. Journal of Business Ethics, 108, 299-312.

Showail, S. J., McClean Parks, J., \& Smith, F. L. (2013). Foreign workers in Saudi Arabia: A field study of role ambiguity, identification, information-seeking, organizational support and performance. International Journal of Human Resource Management, 24, 3957-3979.

Simons, T., \& Peterson, R. S. (2000). Task conflict and relationship conflict in top management teams: The pivotal role of intragroup trust. Journal of Applied Psychology, 83, 102-111.

Singh, P., Suar, D., \& Leiter, M. P. (2012). Antecedents, work-related consequences, and buffers of job burnout among Indian software developers. Journal of Leadership \& Organizational Studies, 19, 83-104.

Sommer, K. L., \& Kulkarni, M. (2012). Does constructive performance feedback improve citizenship intentions and job satisfaction? The roles of perceived opportunities for advancement, respect, and mood. Human Resource Development Quarterly, 23, $177-201$.

Spector, P. E. (2006). Method variance in organizational research: Truth or urban legend? Organizational Research Methods, 9, 221-232.

Sun, S., \& van Emmerik, H. I. (2015). Are proactive personalities always beneficial? Political skill as a moderator. Journal of Applied Psychology, 100, 966-975.

Tierney, P., \& Farmer, S. M. (2002). Creative self-efficacy: Potential antecedents and relationship to creative performance. Academy of Management Journal, 45, 1137-1148.

Tremblay, M., \& Gibson, M. (2016). The role of humor in the relationship between transactional leadership behavior, perceived supervisor support, and citizenship behavior. Journal of Leadership \& Organizational Studies, 23, 39-54.

Trépanier, S.-G., Fernet, C., \& Austin, S. (2013). The moderating role of autonomous motivation in the job demands-strain relation: A two sample study. Motivation and Emotion, 37, 93-105.

Van Knippenberg, D. (2000). Work motivation and performance: A social identity perspective. Applied Psychology: An International Review, 49, 357-371.

Wang, Y., Tang, C., Naumann, S. E., \& Wang, Y. (2019). Paternalistic leadership and employee creativity: A mediated moderation model. Journal of Management and Organization, 25, 137-156.

Wei, Y.-C. (2012). Person-organization fit and organizational citizenship behavior: Time perspective. Journal of Management and Organization, 18, 833-844.

Williams, L. J., \& Anderson, S. E. (1991). Job satisfaction and organizational commitment as predictors of organizational citizenship and in-role behaviors. Journal of Management, 17, 601-617.

Witt, L. A., \& Carlson, D. S. (2006). The work-family interface and job performance: Moderating effects of conscientiousness and perceived organizational support. Journal of Occupational Health Psychology, 11, 343-357.

Yilmaz, E., Ozer, G., \& Gunluk, M. (2014). Do organizational politics and organizational commitment affect the budgetary slack creation in publication organizations. Procedia - Social and Behavioral Sciences, 150, 241-250.

Zahra, S., \& Hayton, J. C. (2008). The effect of international venturing on firm performance: The moderating influence of absorptive capacity. Journal of Business Venturing, 23, 195-122.

Zhang, R.-P., Tsingan, L., \& Zhang, L.-P. (2013). Role stressors and job attitudes: A mediated model of leader-member exchange. Journal of Social Psychology, 153, 560-576.

Zhang, X., Walumbwa, F. O., Aryee, S., \& Chen, Z. X. (2013). Ethical leadership, employee citizenship and work withdrawal behaviors: Examining mediating and moderating processes. Leadership Quarterly, 24, 284-297.

Zhao, H., Wayne, S. J., Glibkowski, B. C., \& Bravo, J. (2007). The impact of psychological contract breach on work-related outcomes: A meta-analysis. Personnel Psychology, 60, 647-680.

Zhao, H., \& Xia, Q. (2017). An examination of the curvilinear relationship between workplace ostracism and knowledge hoarding. Management Decision, 55, 331-346.

Zhou, Q., Martinez, L. F., Ferreira, A. I., \& Rodrigues, P. (2016). Supervisor support, role ambiguity and productivity associated with presenteeism: A longitudinal study. Journal of Business Research, 69, 3380-3387.

Cite this article: De Clercq D, Belausteguigoitia I (2022). Political skill and organizational identification: Preventing role ambiguity from hindering organizational citizenship behaviour. Journal of Management \& Organization 28, 973-992. https://doi.org/10.1017/jmo.2019.31 